\title{
The prevalence of physical activity and its associated effects among students in the São Paulo public school network, Brazil
}

\author{
Prevalência de atividade física e fatores associados \\ em escolares da rede pública estadual de São Paulo, Brasil
}

Leonardo José Silva ${ }^{1}$

Victor Keihan Rodrigues Matsudo ${ }^{2}$

Douglas Roque Andrade ${ }^{3}$

Mário Azevedo ${ }^{4}$

Gerson Luis de Moraes Ferrari ${ }^{2}$

Luis Carlos Oliveira ${ }^{2}$

Timóteo Leandro Araújo ${ }^{2}$

Sandra Marcela Mahecha Matsudo ${ }^{2}$

${ }^{1}$ Instituto Israelita de

Responsabilidade Social

do Hospital Israelita Albert

Einstein. Av. Albert Einsten

627/701, Morumbi. 05652-

900 São Paulo SP Brasil.

ljs.leonardo@gmail.com

${ }^{2}$ Centro de Estudos do

Laboratório de Aptidão

Física de São Caetano do

Sul. R. Heloisa Pamplona

269/31, Bairro Fundação.

09520-320 São Caetano do

Sul SP Brasil.

${ }^{3}$ Escolas de Artes, Ciências e

Humanidades de São Paulo,

Universidade de São Paulo.

São Paulo SP Brasil.

${ }^{4}$ Escola Superior

de Educação Física,

Universidade Federal de

Pelotas. Pelotas RS Brasil.
Abstract The current study evaluated physical activity (PA) level and its associated effects among students in the public network of São Paulo, Brazil. A cross-sectional study was taken using a representative sample of students in São Paulo public school system. International Physical Activity Questionnaire determined PA level. Students who reported at least 300 minutes/week of PA were considered active. The independente variables were: gender, age, body mass index, education, region, recognition of the Agita São Paulo program. The prevalence of regular PA was $71.7 \%$. Males $(P R=1.09,95 \%$ CIs $=1.04-1.15)$ at least 17 years old $(P R=1.16,95 \%$ CIs $1.09-1.24)$ in their 3rd year of high school $(P R=1.20,95 \%$ CIs $=1.12-1.29)$ who resided in the Midwest region $(P R=1.27,95 \%$ CIs 1.16-1.38) were most likely to be active. Males at least 17 years old in their $3 \mathrm{rd}$ year of high school who lived in the Midwest and recognized the Agita São Paulo/Agita Galera program had higher levels of PA. São Paulo students presented a high level of PA. Moreover, males older than 17 years, attending their 3 rd year of high school, who lived in the Midwest region, and recognized the Agita São Paulo/Agita Galera program were the most likely to be more active.

Key words Motor activity, Epidemiology, Public health, Adolescent
Resumo O presente estudo avaliou nível de atividade física (AF) e seus efeitos associados entre estudantes da rede pública de São Paulo. Um estudo transversal foi feito usando uma amostra representativa de estudantes da rede pública de ensino de São Paulo. Foi utilizado o International Physical Activity Questionnaire para determinar o nível AF. Estudantes que relataram pelo menos 300 minutos/semana de AF, foram considerados ativos. As variáveis independentes foram: sexo, idade, indice de massa corporal, educação, região e o conhecimento do programa Agita São Paulo. A prevalência de AF regular foi de 71,7\%. Os meninos $(R P=1,09, I C 95 \%=1,04-1,15), 17$ anos de idade ( $R P=1,16,95 \%$ IC 1,09-1,24), terceiro ano do ensino médio $(R P=1,20, I C 95 \%=1,12-1,29$ ) e aqueles que residiam na região do Centro-Oeste $(R P=1,27$, IC95\% 1,16-1,38) tinham maior probabilidade de ser ativos. Meninos de 17 anos de idade, no terceiro ano do ensino médio, que residiam no Centro-Oeste e reconhecia o programa Agita São Paulo/Agita Galera tinham níveis mais elevados de AF. Alunos de São Paulo apresentaram um elevado nível de AF. Meninos com idade superior a 17 anos, do $3^{\circ}$ ano do ensino médio, que residiam na região Centro-Oeste, e reconhecia o programa Agita São Paulo/Agita Galera foram mais propensos a ser mais ativos.

Palavras-chave Atividade física, Epidemiologia, Saúde pública, Adolescente 


\section{Introduction}

The relationship between physical activity and health has been well established in the literature ${ }^{1}$. However, abundant evidence has also shown that physical inactivity is common among the population, including children and adolescents ${ }^{2}$.

In addition to not enjoying the benefits of physical activity in the short term, sedentary children and adolescents have an increased chance of becoming sedentary adults. Even more troubling, physical activity and participation in physical education courses have decreased over time among adolescents in developed countries ${ }^{3}$.

A high prevalence of physical inactivity has been estimated among adolescents in Brazil. A recent review ${ }^{4}$ found this prevalence to range from $39.0 \%$ to $93.5 \%$. This large variability is due to the different measurements and cutoff points used in studies to classify physical activity levels. In Brazil, there are few population-based studies school of physical activity adolescents ${ }^{5,6}$.

Interventions to increase physical activity have been recently implemented in Brazil ${ }^{7,8}$. The Agita São Paulo program is a pioneering initiative in this country9. Implemented in 1996, this program has increased (at the state level in particular) people's knowledge regarding the biological, psychological, and social health benefits of physical activity and people's involvement in moderate to vigorous physical activity ${ }^{10}$. One of the Agita São Paulo's initiatives is the Agita Galera Program ${ }^{11}$, which aims to promote awareness and physical activity at school among school-age children.

The Agita Galera concept is highly audacious because it aims to affect the entire public school system of São Paulo. According to official data of the Board of Education of São Paulo (Secretaria da Educação do Estado de São Paulo), this school system is currently the largest in Brazil with 5,300 schools, 230,000 teachers, 59,000 staff, and more than 4 million students ${ }^{12}$.

The current study evaluated physical activity level and its associated effects among students from elementary and middle schools in the public network of São Paulo, Brazil.

\section{Methods}

This school-based cross-sectional study was conducted in the state of São Paulo. The sample was selected across multiple stages: a) Random selection occurred within each macro-region of the municipalities (i.e., each administrative region), stratified by size: small municipalities (up to 30,000 inhabitants), medium (30,001 to 199,999 inhabitants), and large (greater than or equal to 200,000 inhabitants). A municipality was selected from each stratum; if the selected area did not have a municipality within its stratum, then two cities were selected from the stratum of the most representative size.

b) Schools were randomly selected in each municipality $($ minimum $=2$; maximum $=17$ ).

c) Students from the 5th and 8th grades as well as the 3rd year of high school were selected from each school $($ minimum $=3$; maximum $=$ 150).

The data were collected between February and May 2011. Trained interviewers approached individuals in the classroom at all schools. To aid in the understanding of the instrument, especially with regard to the intensity of physical activity, flash cards were used with typical physical activities.

The short version of the International Physical Activity Questionnaire (IPAQ) was used to measure physical activity level ${ }^{6,13,14}$. The IPAQ was developed by an international group of experts to estimate physical activity patterns of populations from different countries and sociocultural contexts $^{14}$. The questionnaire is validated for Brazilian adolescents and the IPAQ have acceptable measurement properties for monitoring levels of habitual physical activity in adolescents ${ }^{6}$.

Young adolescents reported their frequencies and durations of walking and other physical activities of moderate to vigorous intensity over the previous week ${ }^{6}$. The content validity of IPAQ is high, because frequency, intensity, and duration of physical activity are assessed, as well as sedentary behavior, which is an emerging concern ${ }^{6,14} \mathrm{~A}$ physical activity score was created by multiplying the weekly frequency and duration of each physical activity session reported. Individuals with a physical activity score of at least 300 minutes/ week were considered active based on the current recommendations for physical activity among adolescents ${ }^{15,16}$. The independent variables were as follows:

a) Gender (male or female);

b) Age (in years, categorized into three groups: 10-14, 15-16, and > 17 years);

c) Body mass index (BMI) was derived from weight and height $\left(\mathrm{kg} / \mathrm{m}^{2}\right)$, and BMI z-score calculated based on reference data from the World 
Health Organization (WHO), classified into four groups: low weight, normal, overweight, and obese $^{17}$;

d) Education (grade at interview date: 5 th grade, 8 th grade, or 3rd year of high school);

e) Region (17 regions according to the division proposed by the Government of São Paulo: Midwest, Mid-east, South-southeast, the Sea Coastal Regions, and Metropolitan Areas);

f) Recognition of the Agita São Paulo program logo and the "Meiorito" mascot from a card with images;

g) The ability to associate the logo and mascot with physical activity, healthy eating, or overall health. For the purposes of the analyses, those who associated the logo or mascot with something other than the above characteristics were grouped with those who reported that they did not know the logo or mascot.

The Ethics Committee of the Faculty of Medical Sciences at Santa Casa de São Paulo (Comitê de Ética da Faculdade de Ciências Médicas da Santa Casa de São Paulo) approved this study. Those responsible signed the Terms of Consent pursuant to Resolution 196/96 of the National Health Council before the interviews.

Descriptive analyses were conducted to obtain absolute numbers and proportions with respective confidence intervals for categorical data. Bivariate analyses between physical activity level and the independent variables were conducted using the chi-square test for heterogeneity (categorical variables) and the linear trend test (ordinal variables). Adjusted analyses for possible confounds were performed using a Poisson regression with robust adjustment for variance. The variables were selected "after the fact", thereby respecting the levels of the pre-established hierarchical mode ${ }^{18}$. Variables with $\mathrm{p}<0.20$ were retained in the final model. The level of significance employed was $\mathrm{p}<0.05$. All analyses were weighted by the representativeness of the municipalities and regions and conducted using Stata version 10.0 .

\section{Results}

The final sample was composed of 51 municipalities in São Paulo, totaling 154 schools and 2,555 students from the 5 th and 8th grades of elementary school as well as the 3rd year of high school in the São Paulo state public school network. Approximately $4 \%$ of schools refused to participate in the study; thus, new schools of the same size were randomly selected within each municipality. As shown in Table 1, the students were predominantly female (56.1\%), aged between 10 and 13 years, and has a normal BMI (69.2\%).

The prevalence of physically active students ( $\geq 300$ minutes/week) in the state was $71.7 \%$ (95\% CI 70.0-73.4). Table 2 displays the association between physical activity and the independent variables. Young males aged at least 17 years old and in their 3rd year of high school were significantly more active than other participants. Region 5, which includes the capital and the metropolitan area, had the lowest prevalence of physical activity.

Table 3 displays the raw and adjusted analyses of the association between physical activity and the independent variables. The adjusted analyses showed the same associated factors as the raw analyses. Young males were $9 \%$ more active than females. Third year high school students were significantly more active compared with students in the 5 th grade with a prevalence ratio of 1.20 $(95 \%$ CIs $=1.12$ to 1.29$)$.

Table 1. The sample demographics of São Paulo public education students in $2008(\mathrm{~N}=2,555)$.

\begin{tabular}{|c|c|c|}
\hline Variables & $\mathbf{N}$ & $\%$ \\
\hline \multicolumn{3}{|l|}{ Gender } \\
\hline Male & 1,122 & 43.9 \\
\hline Female & 1,433 & 56.1 \\
\hline \multicolumn{3}{|l|}{ Age (complete years) } \\
\hline $10-13$ & 1,069 & 41.8 \\
\hline $14-16$ & 706 & 27.6 \\
\hline$\geq 17$ & 780 & 30.6 \\
\hline \multicolumn{3}{|l|}{ Grade } \\
\hline $5^{\text {th }}$ year of elementary school & 774 & 30.3 \\
\hline $8^{\text {th }}$ year of elementary school & 787 & 30.8 \\
\hline $3^{\text {rd }}$ year of high school & 994 & 38.9 \\
\hline \multicolumn{3}{|l|}{$\mathrm{BMI}^{*}$} \\
\hline Low weight & 334 & 13.1 \\
\hline Normal & 1768 & 69.2 \\
\hline Overweight & 159 & 6.2 \\
\hline Obese & 228 & 8.9 \\
\hline \multicolumn{3}{|l|}{ Region } \\
\hline Midwest & 476 & 18.6 \\
\hline Mideast & 597 & 23.4 \\
\hline South-southeast & 478 & 18.7 \\
\hline Coastal regions & 400 & 15.7 \\
\hline Metropolitan region & 604 & 23.6 \\
\hline
\end{tabular}

* Number of missing data: 66; BMI: body mass index. 
Table 2. The prevalence of physical activity $(\geq 300$ minutes/week) among students in São Paulo public education.

\begin{tabular}{lcc}
\multicolumn{1}{c}{ Variables } & $\%$ & p-value \\
\hline Gender & & $<0.001$ \\
Male & 75.7 & \\
Female & 68.7 & \\
Age (complete years) & & $<0.001^{\text {t }}$ \\
10-13 & 65.7 & \\
14-16 & 74.9 & \\
$\geq 17$ & 76.8 & \\
Grade & & $<0.001 \mathrm{t}$ \\
$5^{\text {th }}$ year of elementary school & 63.3 & \\
$8^{\text {th }}$ year of elementary school & 74.1 & \\
$3^{\text {rd }}$ year of high school & 76.4 & \\
Region & & $<0.001$ \\
Midwest & 79.3 & \\
Mideast & 77.4 & \\
South-southeast & 69.6 & \\
Coastal regions & 69.5 & \\
Metropolitan region & 63.2 & \\
BMI & & 0.104 \\
Low weight & 67.0 & \\
Normal & 72.6 & \\
Overweight & 76.0 & \\
Obese & 73.0 & \\
\hline
\end{tabular}

${ }^{\mathrm{t}}$ Linear trend test; BMI: body mass index.

There were no significant differences $(p>$ 0.05 ) among the region for any of the physical activity (walking, moderate and vigorous physical activity) (Table 4).

Table 5 displays the student recognition of the logo and mascot of the Agita São Paulo program: The program logo and mascot were recognized by $39.3 \%$ and $44.1 \%$ of respondents, respectively.

Students who recognized the program logo were significantly more active than those who did not $(76.9 \%$ vs. $68.4 \%, \mathrm{p}<0.001)$. Students who correctly identified the logo and mascot of Agita São Paulo were significantly more active compared with those who did not correctly do so. Analyses adjusted for gender, age, grade, and region confirmed the results of the raw analyses, except for the "identifies the program mascot correctly" variable, which was not significant ( $\mathrm{p}$ $=0.487$; Figure 1 ).

\section{Discussion}

The aim of this study was evaluated physical activity level and its associated effects among stu- dents in the public network of São Paulo, Brazil. We showed that prevalence of physically active students ( $\geq 300$ minutes/week) in the state was $71.7 \%$. Young males were $9 \%$ more active than females. Third year high school students were significantly more active compared with students in the 5th grade. Students who recognized the program logo were significantly more active than those who did not and students who correctly identified the logo and mascot of Agita São Paulo were significantly more active compared with those who did not correctly do so, independent of gender, age, grade, BMI, and region confirmed the results of the raw analyses, except for the "identifies the program mascot correctly" variable, which was not significant.

Although the literature constantly reports technological advances in the methods used to evaluate physical activity in youths, this activity remains challenging ${ }^{19,20}$. A correlation does not exist between data collected via questionnaires and direct methods such as accelerometry with regard to physical activity level. Nevertheless, evidence shows that when individuals are categorized into physical activity groups, these methods can be moderately to highly concordant ${ }^{19}$.

A majority of the youths in our sample $(71.7 \% ; 95 \%$ CIs $=70.0 \%$ to $73.4 \%)$ met the physical activity recommendations. Male aged at least 17 years old in their $3^{\text {rd }}$ year of high school from the Midwest region of the state were most likely to be active. The high prevalence of youths who met these recommendations is a surprising finding.

An instrument commonly used in epidemiological surveys ${ }^{21,22}$ was employed in the present study. Recent studies that have used similar physical activity measures and cutoffs found data that conflicted with those presented here; specifically, they reported high estimates of physical inactivity among adolescents (ranging from $39.2 \%$ to $69.8 \%)^{5,21-23}$.

A sample of high school students who attended public schools in São Paulo showed a low prevalence of physical activity (37.5\%). Of the adolescents who met the recommendation, $47 \%$ practiced structured physical activities in city clubs. The same study found that the prevalence of physical activity ( $\geq 300$ minutes/week) was significantly higher in boys than girls $(50.3 \%$ versus $25.9 \%)^{5}$.

In the present study, boys had significantly higher mean values for physical activity than girls. Our findings agree with recent studies that boys accumulate more physical activity than 
Table 3. The raw and adjusted analyses of the associations between physical activity and demographics, education, and BMI among students of the São Paulo state public education network.

\begin{tabular}{|c|c|c|c|c|}
\hline \multirow{2}{*}{ Variables } & \multicolumn{2}{|c|}{ Raw analysis } & \multicolumn{2}{|c|}{ Adjusted analysis } \\
\hline & PR (CI95\%) & p-value & PR (CI95\%) & p-value \\
\hline Gender & & $<0.001$ & & $<0.001^{\mathrm{a}}$ \\
\hline Male & $1.10(1.04-1.16)$ & & $1.09(1.04-1.15)$ & \\
\hline Female & 1.0 & & 1.0 & \\
\hline Age (complete years) & & $<0.001 \mathrm{t}$ & & $<0.001^{\mathrm{bt}}$ \\
\hline $10-13$ & 1.0 & & 1.0 & \\
\hline $14-16$ & $1.14(1.06-1.22)$ & & $1.14(1.06-1.21)$ & \\
\hline$\geq 17$ & $1.17(1.10-1.25)$ & & $1.16(1.09-1.24)$ & \\
\hline Grade & & $<0.001 \mathrm{t}$ & & $<0.001^{\mathrm{bt}}$ \\
\hline $5^{\text {th }}$ year of elementary school & 1.0 & & 1.0 & \\
\hline $8^{\text {th }}$ year of elementary school & $1.17(1.09-1.26)$ & & $1.17(1.09-1.26)$ & \\
\hline $3^{\text {rd }}$ year of high school & $1.21(1.12-1.29)$ & & $1.20(1.12-1.29)$ & \\
\hline Region & & $<0.001$ & & $<0.001^{\mathrm{c}}$ \\
\hline Midwest & $1.26(1.15-1.37)$ & & $1.27(1.16-1.38)$ & \\
\hline Mideast & $1.23(1.12-1.34)$ & & $1.24(1.13-1.35)$ & \\
\hline South-southeast & $1.10(1.00-1.22)$ & & $1.11(1.01-1.23)$ & \\
\hline Coastal regions & $1.10(1.00-1.21)$ & & $1.09(0.99-1.20)$ & \\
\hline Metropolitan region & 1.0 & & 1.0 & \\
\hline $\mathrm{BMI}^{*}$ & & 0.421 & & $0.250^{\mathrm{d}}$ \\
\hline Low weight & 1.0 & & 1.0 & \\
\hline Normal & $1.06(0.98-1.14)$ & & $1.07(1.00-1.19)$ & \\
\hline Overweight & $1.09(0.97-1.22)$ & & $1.12(0.99-1.26)$ & \\
\hline Obese & $1.05(0.94-1.18)$ & & $1.05(0.94-1.17)$ & \\
\hline
\end{tabular}

${ }^{\mathrm{a}}$ Adjusted for age; ${ }^{\mathrm{b}}$ Adjusted for gender; ${ }^{\mathrm{c}}$ Adjusted for gender, age, and grade; ${ }^{\mathrm{d}}$ Adjusted for gender, age, grade, and macro-region; Linear trend test.

Table 4. Physical activity indicators (minutes/week) by region in São Paulo public education.

\begin{tabular}{lccc}
\hline \multicolumn{1}{c}{ Region } & $\begin{array}{c}\text { Walking } \\
\text { minutes/week (SD) }\end{array}$ & $\begin{array}{c}\text { Moderate physical activity } \\
\text { minutes/week (SD) }\end{array}$ & $\begin{array}{c}\text { Vigorous physical activity } \\
\text { minutes/week (SD) }\end{array}$ \\
\hline Midwest & $223(346)$ & $310(455)$ & $190(370)$ \\
Mideast & $288(506)$ & $318(437)$ & $196(346)$ \\
South-southeast & $223(338)$ & $311(440)$ & $211(398)$ \\
Coastal regions & $192(298)$ & $410(494)$ & $214(332)$ \\
Metropolitan region & $276(401)$ & $412(479)$ & $288(398)$ \\
\hline
\end{tabular}

SD: standard deviation.

girls ${ }^{24-26}$. To describe the physical activity practiced among Brazilian adolescents, data from the National Survey of Student Health (Pesquisa Nacional de Saúde do Escolar [PeNSE] $)^{24}$ were collected from all the Brazilian state capitols and the Federal District in 2009. These data revealed an active youth prevalence of $46 \%$ in São Paulo. This study also observed that the proportion of active boys was higher than that of girls.
Evidence from developed countries has shown that involvement in physical activity during adolescence is declining, even during physical education classes ${ }^{3}$. Data from the Youth Risk Behavior Surveillance System (YRBSS) that sampled participation in high school physical education in the US from 1991 to 2004 revealed that approximately $55 \%$ of students were enrolled in these classes, but only $28 \%$ attended them each 
Table 5. Recognition of the Agita São Paulo program among students $(\mathrm{N}=2,555)$ in the São Paulo state public education network.

Variables
Recognizes the "Agita" logo
No
Yes
Associates the "Agita" logo with physical
activity, sport, leisure, or health
No $^{\text {a }}$
Yes
Recognizes the program mascot
No
Yes
Associates the program mascot with
physical activity, sport, leisure, or health
No
Yes

${ }^{\mathrm{P}}$ Analyses weighted by region; ${ }^{\mathrm{a}}$ Individuals who reported not recognizing the Agita logo and those who did not associate the logo with physical activity, healthy eating, or health in general; ${ }^{b}$ Individuals who reported not recognizing the program mascot and those who did not associate the program mascot with physical activity, healthy eating, or health in general.

day. In 2011, 53.3\% of US students were enrolled in physical education classes, and only $23 \%$ attended these classes every day ${ }^{27}$.

A systematic review of the interventions conducted in Latin America showed that school interventions effectively promote physical activity $^{28}$. However, the strategies aimed at greater student involvement primarily within schools remain a global challenge. In São Paulo, the 1997 implementation of the Agita Galera Program (Active Community Day) in the public school system involved various discussions of the importance of physical activity. These discussions have included the sensitization of teachers in the public education network, publicity via printed media, the preparation and distribution of informational handouts, and encouraging schools to promote specific and permanent actions related to physical activity, among others.

A study of public high school students in São Paulo examined the prevalence of physical inactivity with regard to knowledge of the Agita São Paulo/Agita Galera program and found that a lack of knowledge increased the likelihood of inactivity by $29 \%(\mathrm{PR}=1.2 ; 95 \% \mathrm{CIs}=1.16-1.38)^{5}$.

Our study revealed that individuals who reported recognizing the program logo were significantly more active than those who did not
(76.9\% vs. $68.4 \%, \mathrm{p}<0.001)$. Several hypotheses might explain the high prevalence of the student physical activity detected in this study. These data might indicate that the Agita São Paulo/Agita Galera program positively influences the physical activity levels of students in the public education network of São Paulo. This supposition is reinforced by the fact that the event has occurred annually since 1997.

To the best of our knowledge, national studies have not analyzed the temporal trends of student physical activity. A study of adults from southern Brazil used the same physical activity evaluation and found an increase of $11 \%$ in adult in activity (150-minutes/week) from 2002 to $2007^{24}$. Data from the Brazilian monitoring system Vigitel revealed a modest increase in the proportion of adults who practiced a minimum of $150 \mathrm{~min} /$ week of physical activity during their leisure time nationwide $(14.9 \%$ in $2006 ; 15.5 \%$ in 2007 ; and $16.4 \%$ in 2008$)^{29}$. However, these data are not directly comparable because they used different physical activity domains to classify their sample.

Furthermore, São Paulo has officially commemorated World Physical Activity Day (April 6) since 2002. On this day, several cities in the state promote large events that target the need to incorporate physical activity into one's daily life. For example, in 2002, 888 events were held across 175 municipalities. In 2008, more than 2,030 events were held. In addition, the Brazilian Ministry of Health has funded city projects that encourage physical activity since 2006. Of the 35 municipalities of São Paulo given the award in 2006, 54\% were partners of the Agita São Paulo program.

Recognition of the Agita logo has increased in recent years. In 2002, 37\% of the state's population was aware of Agita; in 2008, this statistic increased to $60 \%$. To date, $49 \%$ of the state's population has become aware of the primary message of the program ${ }^{30}$.

We stress that students who recognized the program's logo were significantly more active than those who did not $(76.9 \%$ vs. $68.4 \%, \mathrm{p}<$ 0.001; Figure 1). In addition, the data collection and interviews were conducted between February and March, far removed from August when the Agita Galera events are held. Thus, the program likely is sustainable and permanent among public school students. Therefore, the results presented in our study and current scientific evidence suggest that the engagement of adolescents in physical activities stimulated by health promotion programs at school or not could contribute 


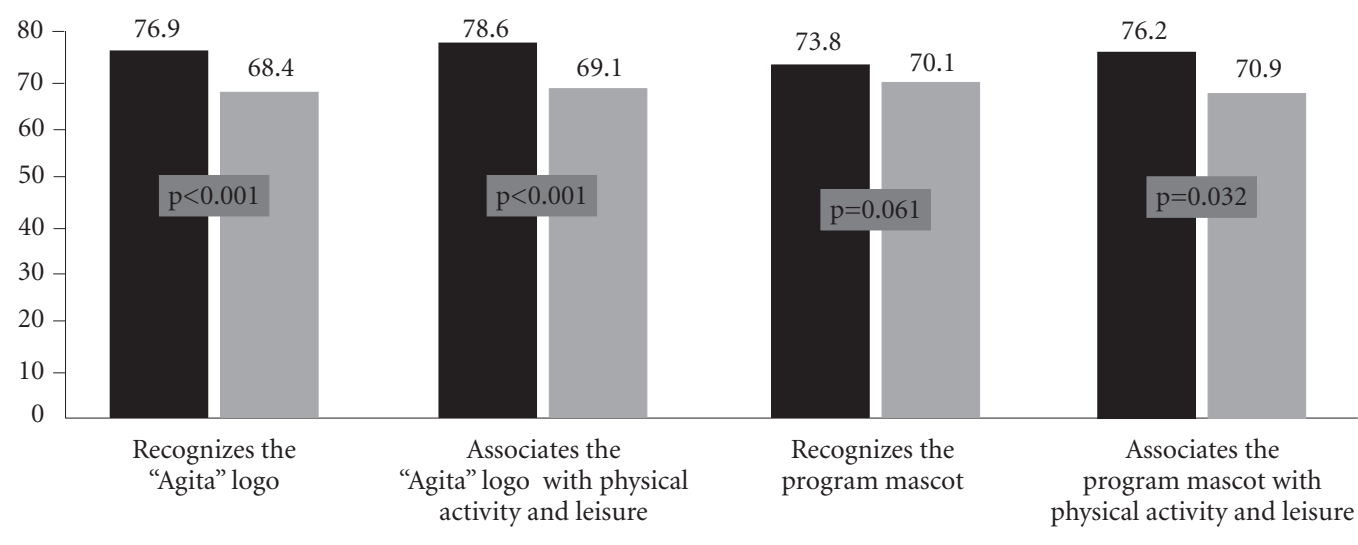

Figure 1. The prevalence of physical activity* ( $\geq 300$ minutes/week) by the recognition of the Agita São Paulo program among students of the São Paulo public education network.

* Adjusted for gender, age, grade, BMI and macro-region.

to the reduction of physical inactivity, probably because it raises awareness of the importance and benefits for health and also due to the greater involvement of adolescents in these activities. In that sense, the action of schools and governmental agencies seems to be an interesting manner to create and implement intervention programs that assist to prevent physical inactivity.

Some limitations of the present study need to be acknowledged. The short version of IPAQ also has some limitations. The main limitation is that we were unable to differentiate domains of physical activity (leisure time, occupational, housework, and commuting). In a country like Brazil most previous research has used questionnaires (IPAQ) indirect measures of physical activity for adolescents ${ }^{6}$. Questionnaires, like IPAQ, represent the most accessible instrument for the usual physical activity evaluation, above all in epidemiological nature studies due to the easiness of being applied to large groups, low cost and for allowing collecting information with relation to the type and context in which they are performed, what does not occur to other measurement resources. In the present study, only high school students from state's public schools who attended school in the mornings were assessed. Thus, other segments that are part of the educational system, such as private, city's public or technical schools and other school hours (afternoon or evening classes) were not assessed. Accordingly, our inferences are related only to the group studied. The results shown in the present study may serve as the basis for future investigations in areas with specific environmental and social characteristics in the state of São Paulo, providing data for comparisons with both studies involving young populations from other regions in Brazil and youths from other countries.

\section{Conclusion}

The present findings indicate that students in São Paulo have a high level of physical activity. Moreover, males older than 17 years attending their 3rd year of high school who lived in the Midwest region and recognized the Agita São Paulo/Agita Galera program were the most likely to report physical activity. At least some of our findings directly or indirectly reflect the positive effect of the Agita São Paulo/Agita Galera program on the activity level of students in São Paulo, Brazil.

\section{Collaborations}

LJ Silva, VKR Matsudo, DR Andrade, M Azevedo, GLM Ferrari, LC Oliveira, TL Araújo e SMM Matsudo contributed equally to the preparation of the manuscript. 


\section{Acknowledgements}

State Department of Health of São Paulo.

\section{References}

1. Bouchard DR, Langlois MF, Boisvert-Vigneault K, Farand P, Paulin M, Baillargeon JP. Pilot study: can older inactive adults learn how to reach the required intensity of physical activity guideline? Clin Interv Aging 2013; 8:501-518.

2. Hallal PC, Andersen LB, Bull FC, Guthold R, Haskell W, Ekelund U. Global physical activity levels: surveillance progress, pitfalls, and prospects. Lancet 2012; 380(9838):247-257.

3. Knuth AG, Hallal PC. Temporal trends in physical activity: a systematic review. J Phys Act Health. 2009;6(5):548-559.

4. Tassitano RM, Bezerra J, Tenório MCM, Colares V, Barros MVG, Hallal PC. Physical activity in Brazilian adolescents: A systematic review. Rev Bras Cineantropom Desempenho Hum 2007; 9(1):55-60.

5. Ceschini FL, Andrade DR, Oliveira LC, Araújo Júnior JF, Matsudo VKR. Prevalência de inatividade física e fatores associados em estudantes do ensino médio de escolas públicas estaduais. J Pediatr 2009; 85(4):301-306.

6. Guedes DP, Lopes CC, Guedes JERP. Reproducibility and validity of the International Physical Activity Questionnaire in adolescents. Rev Bras Med Esporte 2005; 11(2):147-154

7. Malta D, Castro A, Gosh C, Cruz DKA, Bressan A, Nogueira JD, Morais Neto OL, Temporão JG. National policy of health promotion and the motor activity agenda in the context of the National Health System in Brazil. Epidemiol Serv Saúde 2009; 18(1):79-86.

8. Matsudo SM, Matsudo VR, Araujo TL. The Agita Sao Paulo Program as a model for using physical activity to promote health. Rev Panam Salud Publica 2003; 14(4):265-273.

9. Matsudo V, Guedes J, Matsudo S, Andrade D, Araujo T, Oliveira L, Andrade E, Ribeiro M. Policy intervention: the experience of Agita São Paulo in using "mobile management" of the ecological model to promote physical activity. Perspectives 2004; 6:1-22.

10. Matsudo SMM, Matsudo VKR, Araújo TL, Andrade E, Oliveira L, Braggion G. Physical activity promotion: experiences and evaluation of the Agita São Paulo Program using the ecological mobile model. J Phys Act Health 2004; 1:81-97.

11. Zieff SG, Guedes CM, Wiley J. Youth knowledge of physical activity health benefits: a brazilian case study. ScientificWorldJournal 2006; 6:1713-1721.

12. Secretaria da Educação do Estado de São Paulo. A Secretaria. [cited 2013 Jul 16]. http://www.educacao. sp.gov.br/portal/institucional/a-secretaria 
13. Matsudo S, Araújo T, Matsudo V, Andrade D, Andrade E, Oliveira LC, Braggion G. Questionário internacional de atividade física (IPAQ): estudo de validade e reprodutibilidade no Brasil. Rev Bras Ativ Fís Saúde 2001; 6(2):5-18

14. Craig CL, Marshall AL, Sjostrom M, Bauman AE, Booth ML, Ainsworth BE, Pratt M, Ekelund U, Yngve A, Sallis JF, Oja P. International physical activity questionnaire: 12 -country reliability and validity. Med Sci Sports Exerc 2003; 35(8):1381-1395.

15. Strong WB, Malina RM, Blimkie CJ, Daniels SR, Dishman RK, Gutin B, Hergenroeder AC, Must A, Nixon PA, Pivarnik JM, Rowland T, Trost S, Trudeau F. Evidence based physical activity for school-age youth. J Pediatr. 2005; 146(6):732-737.

16. World Health Organization (WHO). Global recommendations on physical activity for health. Geneva: WHO; 2010.

17. de Onis M, Onyango AW, Borghi E, Siyam A, Nishida C, Siekmann J. Development of a WHO growth reference for school-aged children and adolescents. Bull World Health Organ 2007; 85(9):660-667.

18. Barros AJ, Hirakata VN. Alternatives for logistic regression in cross-sectional studies: an empirical comparison of models that directly estimate the prevalence ratio. BMC Med Res Methodol 2003; 3:21-33.

19. Reimers AK, Mess F, Bucksch J, Jekauc D, Woll A. Systematic review on measurement properties of questionnaires assessing the neighbourhood environment in the context of youth physical activity behaviour. BMC Public Health 2013; 13:461.

20. Ferrari GL, Oliveira LC, Araujo TL, Matsudo V, Barreira TV, Tudor-Locke C, Katzmarzyk P. Moderate-to-vigorous physical activity and sedentary behavior: independent associations with body composition variables in brazilian children. Pediatr Exerc Sci 2015; 27(3):380389.

21. Gonçalves H, Hallal PC, Amorim TC, Araújo CLP, Menezes AMB. Fatores socioculturais e nível de atividade física no início da adolescência. Rev Panam Salud Publica 2007; 22(4):246-253.

22. Nahas MV, Barros MVG, Goldfine BD, Lopes AS, Hallal PC, Farias junior JC, Oliveira ES. Atividade física e hábitos alimentares em escolas públicas do ensino médio em diferentes regiões do Brasil: o projeto Saúde na Boa. Rev Bras Epidemiol 2009; 12(2):270-277.
23. Castro IRR, Cardoso LO, Engstrom EM, Levy RB, Monteiro CA. Vigilância de fatores de risco para doenças não transmissíveis entre adolescentes: a experiência da cidade do Rio de Janeiro, Brasil. Cad Saude Publica 2008; 24(10):2279-2288.

24. Hallal PC, Knuth AG, Cruz DKA, Mendes MI, Malta DC. Prática de atividade física em adolescentes brasileiros. Cien Saude Colet 2010; 15(Supl. 2):3035-3042.

25. Barreira TV, Schuna Junior JM, Mire EF, Broyles ST, Katzmarzyk PT, Johnson WD, Tudor-Locke C. Normative steps/day and peak cadence values for united states children and adolescents: National Health and Nutrition Examination Survey 2005-2006. J Pediatr 2015; 166(1):139-143.

26. Tudor-Locke C, Craig CL, Beets MW, Belton S, Cardon GM, Duncan S, Hatano Y, Lubans DR, Olds TS, Raustorp A, Rowe DA, Spence JC, Tanaka S, Blair SN. How many steps/day are enough? for children and adolescents. Int J Behav Nutr Phys Act 2011; 8:78.

27. Eaton DK, Kann L, Kinchen S, Shanklin S, Flint KH, Hawkins J, Harris WA, Lowry R, McManus T, Chyen D, Whittle L, Lim C, Wechsler H; Centers for Disease Control and Prevention. Youth Risk Behavior Surveillance - United States, 2011. MMWR Surveill Summ 2012; 61(4):1-162.

28. Hoehner CM, Soares J, Parra Perez D, Ribeiro IC, Joshu CE, Pratt M, Legetic BD, Malta DC, Matsudo VR, Ramos LR, Simões EJ, Brownson RC. Physical activity interventions in Latin America: a systematic review. Am J Prev Med 2008; 34(3):224-233.

29. Monteiro CA, de Moura EC, Jaime PC, Lucca A, Florindo AA, Figueiredo ICR, Bernal R, Silva NN. Surveillance of risk factors for chronic diseases obtained via telephone interviews. Rev Saude Publica 2005; 39(1):47-57.

30. Matsudo VKR, Matsudo SM, Araújo TL, Andrade DR, Oliveira LC, Hallal PC. Time trends in physical activity in the state of Sao Paulo, Brazil: 2002-2008. Med Sci Sports Exerc 2010; 42(12):2231-2236.

Artigo apresentado em 22/06/2015

Aprovado em 27/10/2015

Versão final apresentada em 29/10/2015 
